\title{
Acceptance Rate of Independent Exercise Mobile Based Learning Application Using Android
}

\author{
Arifah Bintarti ${ }^{1}$, and Djoko Rahardjo ${ }^{2}$ \\ ${ }^{1,2}$ Universitas Terbuka, Tangerang Selatan, Banten, Indonesia \\ e-mail: arifahb@ecampus.ut.ac.id
}

\begin{tabular}{|c|c|}
\hline Article Info & Abstract \\
\hline $\begin{array}{l}\text { Article history: } \\
\text { Received } \\
\text { Apr } 12^{\text {th }}, 2021 \\
\text { Revised } \\
\text { May } 19^{\text {th }}, 2021 \\
\text { Accepted } \\
\text { May } 26^{\text {th }}, 2021 \\
\text { Published } \\
\text { July } 30^{\text {th }}, 2021\end{array}$ & $\begin{array}{l}\text { Universitas Terbuka (UT) has prepared many learning services, one of which is In- } \\
\text { dependent Exercises that can be used by students in the learning process. The still } \\
\text { low utilization of IE by students needs to be examined. This paper will discuss the } \\
\text { extent of IE-based mobile learning using Android. This study uses a quantitative } \\
\text { descriptive method, with a population of } 180 \text { respondents, and with a sample of } 71 \\
\text { respondents form the cities of Serang, Bogor, Bandung, Yogyakarta, Manado, and } \\
\text { Pangkal Pinang. Te results of the study show that the aspects of the ease of use, the } \\
\text { usefulness, and the intention to use the Android Indepedent Exercises application } \\
\text { generaly accepted by students, and it is supported by the access rate of them. }\end{array}$ \\
\hline
\end{tabular}

Keywords: independent training; online learning services; mobile learning; android

\begin{tabular}{l}
\hline Abstrak \\
\hline Universitas Terbuka (UT) telah menyiapkan banyak layanan pembelajaran, salah \\
satunya adalah Latihan Mandiri yang dapat digunakan oleh mahasiswa dalam \\
proses pembelajaran. Masih rendahnya pemanfaatan IE oleh mahasiswa perlu \\
dicermati. Makalah ini akan membahas sejauh mana pembelajaran mobile ber- \\
basis IE menggunakan Android. Penelitian ini menggunakan metode deskriptif \\
kuantitatif, dengan jumlah populasi 180 responden, dan dengan sampel 71 re- \\
sponden dari Kota Serang, Bogor, Bandung, Yogyakarta, Manado, dan Pangkal \\
Pinang. Hasil penelitian menunjukkan bahwa aspek kemudahan penggunaan, \\
kemanfaatan, dan niat menggunakan aplikasi Latihan Mandiri Android secara \\
umum diterima oleh siswa, dan didukung oleh tingkat akses mereka.
\end{tabular}

Kata Kunci: pelatihan mandiri; layanan pembelajaran online; mobile learning; android 


\section{INTRODUCTION}

Open University (UT) as an open and distance higher education, urgently needs media in its learning process, in fact these educational institutions have utilized the development of several media. There are many learning services that have been developed one of which is the online learning service features available on the UT website called Web-based Independent Exercises (WIE)

While based on research conducted by Sigit (2013) about the use of Short Message System (SMS) as one of them is Independent Exercise. The results showed that students who were in big cities and were already literate in the internet media refuse to use SMS, while students who live far from urban areas were limited internet computer facilities felt helped by the existence of learning through this SMS.

Independent Exercise IE is one of the learning services provided by UT for its students, and IE is now in a SCORM format that can be downloaded from the UT web site, students can use the application offline on a computer (PC). But in fact, there are some students who report having difficulty in working on IE with the SCORM application. For this reason, students can use IE to provide IE services on Tutorial Online that can be accessed via smart phones. This is in line with research Rahardjo D (2016) about android mobiles, where making an Android-based IE prototype can be obtained information that students can accept this technology as a useful learning service because of the nature of smartphones are flexible to carry and to flexible as learning media. Using a smartphone as a learning medium enables students to access wherever they are, in their free time, because only by opening a smartphone where there is an internet network student can study.

\section{METHOD}

The instrument of the research were two kinds, i.e., application of Android -based Independent Exercises (AIE) Android based and a questionnaire. The application was uploaded to Google Play, and the respondents were emailed to download and install it. In other weeks the researcher came to the spot (in the town of Regional Offices) to interview and observe them. This research is only limited to Bachelor of Communication Studies students who already know or have downloaded AIE for SKOM4321 Public Opinion courses and SKOM4313 Interpersonal Communication courses available on android mobiles. Information about AIE that can be downloaded on android mobiles is still limited to students who are respondents in this study. This research uses survey methods and in-depth interviews. The sample in this study was 71 respondents. Regional Offices that the students enrol the courses were Bogor, Bandung, Manado, Yogjakarta, Serang and Pangkal Pinang.

AIE application has been tried and used by students and downloaded through Google Play or Play Store and then it is installed on the student's mobile phone where then students can practice AIE in 45 items in the Public Opinion course (SKOM4321). Survey using questionnaire which was adopted form Davis (1996).

\section{RESULTS AND DISCUSSION}

Android-based Independent Exercises (AIE) based on mobile learning using Android has been tried and used by students and downloaded through Google Play or Play Store and then is installed on the student's mobile phone offline where then students can practice IE in 45 items in the Public Opinion course (SKOM4321). Furthermore, to find out in more detail about the level of IE-based acceptance of mobile learning using Android which is seen from the aspects of perceived usefulness, perceived usefulness, and intention to use the AIE application in the following details.

\section{Demographic Characteristics of Respondent}

From Table 1 about the status of respondents. From this diagram, information can be obtained that more than $80 \%$ of respondents are not married, only $14 \%$ are married, based on interviews conducted by researchers obtained information also that respondents are still easy and enthusiastic. Respondents are also well informed because the majority of respondents have several social media groups such as WhatsApp, Facebook, Twitter, Instagram, line as well as several other social media. Further information can be obtained that more than $60 \%$ of respondents are women, from this diagarm can be obtained information that the S-1 Communication Studies program is indeed more attractive to women. From interviews conducted at the time of data collection, information can be obtained that the majority of respondents are women who are already working and they always take time to attend or follow tutorials and also follow new academic information (respondents are well informed) of academic information at UT. Next to obtain information on the origin of the respondent can be seen in Table 1 . 
IKOMIK: Jurnal Ilmu Komunikasi dan Informasi 1(1) 2021 16-19

Table 1. Demographical Data of Respondents

\begin{tabular}{lccccc}
\hline \multirow{2}{*}{ Regional Offices } & \multirow{2}{*}{ All } & \multicolumn{2}{c}{ Gender } & \multicolumn{2}{c}{ Married Status } \\
\cline { 2 - 6 } & & Male & Female & Yes & No \\
\hline Serang & 5 & 0 & 5 & 1 & 4 \\
Bogor & 31 & 12 & 19 & 4 & 25 \\
Bandung & 21 & 7 & 14 & 1 & 20 \\
Pangkalpinang & 3 & 1 & 2 & 2 & 1 \\
Yogyakarta & 5 & 1 & 4 & 0 & 4 \\
Manado & 6 & 5 & 1 & 2 & 4 \\
\hline Total & 71 & 26 & 45 & 10 & 58 \\
\hline
\end{tabular}

Table 2. Access Rate

\begin{tabular}{lccccc}
\hline \multicolumn{1}{c}{ Indicators } & Low & Medium & High & Mean & St Deviation \\
\hline More 1 Handphone Ownership & 45 & 6 & 18 & 2,084507 & 1,645309 \\
Operating the tool & 0 & 1 & 68 & 4,704225 & 0,900704 \\
Download Google play & 0 & 1 & 68 & 4,71831 & 0,897347 \\
Internet connection & 4 & 13 & 52 & 3,943662 & 1,217578 \\
Alternating Access Areas & 4 & 13 & 52 & 4,098592 & 1,172969 \\
Balance cost \& usefulness & 1 & 9 & 58 & 4,169014 & 1,158643 \\
\hline
\end{tabular}

Table 3. Easiness Rate

\begin{tabular}{lccccc}
\hline \multicolumn{1}{c}{ Indicators } & Low & Medium & High & Mean & St Deviation \\
\hline Easy to use & 1 & 7 & 61 & 4.366197 & 1.045254 \\
Simple Instruction & 1 & 9 & 59 & $4 ., 295775$ & 1.060921 \\
Easy Question & 1 & 8 & 60 & 4,183099 & 1.059782 \\
Good Interaction & 0 & 17 & 52 & 4.140845 & 1.086222 \\
Good display & 2 & 14 & 53 & 4.000000 & 1.069045 \\
\hline
\end{tabular}

Table 4. Usefulness Rate

\begin{tabular}{lccccc}
\hline \multicolumn{1}{c}{ Indicators } & Low & Medium & High & Mean & St. Deviation \\
\hline Manageable time & 2 & 9 & 55 & 4.0141 & 1.4292 \\
Practicable everywhere & 1 & 4 & 61 & 4.2817 & 1.3542 \\
Increase Understanding & 1 & 7 & 58 & 4.1549 & 1.3591 \\
Increase Motivation & 1 & 7 & 58 & 4.1690 & 1.3626 \\
Improve Effectiveness & 0 & 9 & 57 & 4.1127 & 1.3368 \\
Useful Feedback & 0 & 10 & 55 & 4.0704 & 1.4375 \\
Measurable Competence & 2 & 5 & 59 & 4.1972 & 1.3796 \\
\hline
\end{tabular}

\section{Access Rate}

Generally, the respondents have smartphone it is only 18 respondents who stated they have more than one. The respondents commonly have internet skills such as how to operate and how to download the application from Google Play or Play Store. They also stated that there is in balance between cost and the usefulness of the tool. The internet connection some respondent rather weak and they can use alternatively move to other nearby places.

\section{Easiness Rate}

One of the information obtained from the results of this study is in Table 3. it shows that more than 61 of respondents stated that through the AIE application obtained convenience because it displays the understandable question, and simple instruction. In addition, there is also ease of the AIE application in good interaction and screen display. 
Arifah Bintarti, and Djoko Rahardjo, Acceptance Rate of Independent Exercise Mobile Based ...

Table 5. Intention to Use Rate

\begin{tabular}{lccccc}
\hline \multicolumn{1}{c}{ Indicators } & Low & Medium & High & Mean & St. Deviation \\
\hline Plan to use similar app & 1 & 8 & 57 & 4.1690 & 1.3731 \\
Intent to continue using app & 0 & 9 & 57 & 4.1268 & 1.3409 \\
Willing to share to others & 1 & 10 & 54 & 4.0282 & 1.4538 \\
Measure competence next & 1 & 9 & 56 & 4.0845 & 1.3601 \\
Optimize course values & 0 & 5 & 61 & 4.2817 & 1.3329 \\
\hline
\end{tabular}

\section{Usefulness Rate}

In fact, that using cellular phone can be anywhere. Table 4 shows that 61 of respondents stated that the AIE application practicable everywhere, the application is also useful because it can provide feedback on the material delivered.

That's all the application is also useful because it increases the effectiveness of learning, increases learning motivation, increases understanding of the material, makes the use of the application makes it convenient and safe because it is handy (easy to carry anywhere) also the AIE application makes respondents practice by adjusting their own time

\section{Intent to Use Rate}

Highest indicator in the variable Intent to use Rate is the application can optimize course values. From Table 5 information can be obtained that 61 of respondents stated that they would use the AIE application to achieve optimal value, the intention would be to use this application to measure their competence, also the intention to inform this application to their friends, the intention will be to use this application because it is suitable and will continue to use this IE application if there are other courses available on the IE.

\section{CONCLUSION}

From the discussion it can be concluded: a) The level of student acceptance of Android based Independent Exercises (AIE) application in undergraduate students of Communication Studies consists of 3 aspects, namely the aspects of usefulness, ease of use and ease of use intention to use (behavioral intention), b) Aspects of usefulness (usefulness) of students to the ease of AIE Bachelor of Communication Studies program is more than $80 \%$ of respondents said the AIE application has benefits because it can measure material understanding, can improve motivation to learn, can practice anywhere, can improve understanding of the material, c) The aspect of ease of use of AIE application is $>70 \%$ of respondents said there is ease because AIE displays a good interaction, there are instructions on application easy to understand, the presence of feedback makes it easy to understand, d) The aspect of intention to use (behavioral intention) is more than $80 \%$ of respondents declare intention to use application because it expects to get optimal results, and will continue to use this application if there are other courses in the AIE application. Acceptance rate of the AIE application is more than $80 \%$.

\section{REFERENCES}

Belawati, T. (2002). Perkembangan Pemikiran Tentang Pendidikan Terbuka dan Jarak Jauh. Jakarta: Universitas Terbuka

Creswell, J. W. (2014). Research Design: Qualitative, Quantitative and Mixed Methods Approaches (4th ed.). Thousand Oaks, CA: Sage

Davis, F. D., \& Venkatesh, V. (1996). A critical assessment of potential measurement biases in the technology acceptance model. International Journal of HumanComputer Studies, 45, 19-45.

Fishbein, M. \& Ajzen, I. (1975). Belief, attitude, intention and behavior: an introduction to theory and research Reading, MA: Addison-Wesley.

Moore MG, Kearsley G. 2012. Distance Education: A System View. Wadsworth:Publishing Company, US

Neuman, W L. 2014. Social Research Methods Qualitative and Quantitative Approaches. $7^{\text {rd }}$ ed. By Allyn \& Bacon, Pearson Education Limited, US

Suparman, A. (2004). Pendidikan Jarak Jauh: Teori dan Praktek.Tangerang Selatan : Universitas Terbuka

Sigit, A. (2013). Pemanfatan Latihan Mamdiri Sebagai Bahan Tutorial Bagi Mahasiswa Program Studi Agribisnis Melalui Fasilitas SMS. Jurnal Pendidikan Terbuka dan Jarak Jauh, 14 (1)

Suparman, A. (2004). Pendidikan jarak jauh: Teori dan praktek. Tangerang: Universitas Terbuka.

Susanti (2007). Pengaruh faktor internal mahasiswa terhadap partisiapsi mahasiswa dalam tutorial online. Jurnal Pendidikan Terbuka dan Jarak Jauh, 8 (1), pp. 68-82.

Yuliana E (2009). Persepsi Mahasiswqa Terhadap Tutorial Online Mata kuliah Pengelolaan Wilayah Pesisir dan Laut, Jurnal Pendidikan Tinggi Terbuka Jarak Jauh, 10 (2), pp. 110-127 